\title{
Determination of iron-porphyrin-like complexes at nanomolar levels in seawater
}

\author{
Vong Lilita ${ }^{a}$, Laës Agathe ${ }^{b}$ and Blain Stéphane ${ }^{a_{1} *}$ \\ a Laboratoire d'Océanographie et de Biogéochimie, Université de la Méditerranée, Centre d'Océanographie de \\ Marseille (OSU), Unité Mixte de Recherche CNRS 6535, Campus de Luminy, Case 901, 163, Avenue de Luminy, \\ F-13288 MARSEILLE Cedex 09, France \\ Ifremer, Département TSI, Centre de Brest, BP 70, 29280 Plouzané, France
}

* Corresponding author. Tel.: +334918293 69; fax: +33491821991

E-mail address: stephane.blain@com.univ-mrs.fr (S. Blain)

\begin{abstract}
:
A new method for the non-specific determination of iron-porphyrin-like complexes in natural waters has been developed. It is based on the chemiluminescent oxidation of the luminol in the presence of dioxygen $\left(\mathrm{O}_{2}\right)$ at $\mathrm{pH}$ 13. The method has been implemented in a FIA manifold that allowed the direct injection of seawater. The limit of detection is $0.11 \mathrm{nM}$ of equivalent hemin (Feprotoporphyrin IX). $\mathrm{Fe}^{2+}, \mathrm{Fe}^{3+}, \mathrm{H}_{2} \mathrm{O}_{2}$, siderophore (deferoxamin mesylate), humic acid and phytic acid did not interfere when they were present at the concentrations expected in seawater. Metal free porphyrin and $\mathrm{Mg}, \mathrm{Cu}$, Co porphyrin complexes did not induce a significant chemiluminescent signal. Poisoned unfiltered samples could be stored for several weeks before analyses. The new method was successfully applied to the determination of the Fe-porphyrin complex contained in cultured phytoplankton and in natural samples.
\end{abstract}

Keywords: iron, porphyrin, seawater, flow injection, complexation, chemiluminescence 


\section{Introduction}

During recent years, considerable attention has been paid to the biogeochemistry of iron in seawater because this metal limits phytoplanktonic growth in large oceanic regions $\left[{ }^{1-3}\right]$. The solubility and bioavailability of iron is largely controlled by its chemical speciation that is still poorly understood. Almost all dissolved iron (DFe), supposed to be the major source of iron for microorganisms, is bound by organic ligands that are still largely unidentified $\left[{ }^{4}\right]$. Complementary analytical approaches are used to elucidate the chemical speciation of iron in seawater. Using Cathodic Stripping Voltammetry (CSV) $\left.{ }^{[-11}\right]$ two distinct classes of binding ligands were discovered according to their conditional affinity constant for iron. The stronger ligands are suspected to be siderophores. These molecules are excreted by bacteria to acquire iron $\left[{ }^{12}{ }^{13}\right]$. The identification of siderophore produced by marine organisms has been done using Mass Spectrometry (MS) $\left[{ }^{14},{ }^{15}\right]$ that can be coupled with High Performance Liquid Chromatography (HPLC) $\left.{ }^{[16}\right]$. Although this method allows the complete determination of the chemical structure of the molecules it requires large volumes of seawater and time consuming separation protocols. The other class of ligands with lower conditional affinity constant might include porphyrins $\left[^{5}\right]$. Porphyrins are molecules biosynthesized in almost all living organisms. They are characterised by a tetrapyrrolic ring that allows the complexation of different metal cations. This is the case for iron, leading to Fe-porphyrin (Fe-Py) complexes that are found in various metalloproteins involved in essential biochemical functions, such as photosynthesis, respiration, and nitrogen fixation $\left.{ }^{17}\right]$. Catalase, peroxidase, cytochrome, hemoglobin, myoglobin are some examples of proteins containing Fe-Py complexes playing a key role in enzymatic reactions involved in the electron transfer or the oxygen transport. Although these molecules might be released in aquatic environments following cell degradation or passive excretion, they have not yet been identified as dissolved species in natural waters.

Our work aimed to develop a new method for the measurement of Fe-Py-like complexes in seawater. The method used Flow Injection Analysis (FIA) and chemiluminescence detection. The oxidation of luminol has already been applied to the determination different chemical species in natural waters $\left[{ }^{18}\right]$. In most of the methods, the oxidant is hydrogen peroxide $\left[{ }^{19-21}\right]$. However, the oxidation of luminol by $\mathrm{O}_{2}$ dissolved in the reagents has been applied to the determination of $\mathrm{Fe}$ (II) $\left.{ }^{22-24}\right]$ or $\mathrm{Fe}$ (II) $+\mathrm{Fe}$ (III) $\left.{ }^{25,26}\right]$. Recently, Ussher and co-workers reported that organic compounds interfere in current luminol-chemiluminescence methods used for iron determination $\left.{ }^{27}\right]$. These authors attributed these to interactions with iron species rather than chemiluminescence induced by organic ligands themselves. Fe-Py complexes are also known to promote the luminol oxidation by $\mathrm{O}_{2}$ at $\mathrm{pH} 13$ in immunoassays $\left[{ }^{28,}{ }^{29}\right]$. The objective of the present study was to implement this chemical reaction in a flow injection system and to apply the FIA method to the determination of Fe-Py in natural waters.

\section{Experimental}

\subsection{Reagents and solutions}

All plasticware was cleaned with a detergent (MICRO ${ }^{2}$; International Products Corporation), $\mathrm{NaOH} 0.1 \mathrm{M}, \mathrm{HCl} 10 \%$ and ultrapure deionized water (Milli-Q, Millipore Co.). The solutions of $\mathrm{NaOH}$ $(0.1$ and $0.5 \mathrm{M}$ ) were prepared by dissolving $4 \mathrm{~g}$ or $20 \mathrm{~g}$ of $\mathrm{NaOH}$ pellets in $1 \mathrm{~L}$ of $\mathrm{MQ}$ water. The solution of luminol $\left(1.5 \times 10^{-3} \mathrm{M}\right)$ was prepared by dissolving $177.2 \mathrm{mg}$ of 5-amino-2,3-dihydro-1,4phthalazinedione in $1 \mathrm{~L}$ of $\mathrm{NaOH}(0.1 \mathrm{M}$ or $0.5 \mathrm{M})$ containing $3 \mathrm{~mL}$ of linoleic acid $60 \%$. These reagents were stored in opaque bottles for at least $24 \mathrm{~h}$ prior to use. The solution of EDTA (0.25 M) was obtained by dissolving trisodium ethylenediaminetetraacetate dihydrate in $\mathrm{MQ}$ water. The artificial seawater was composed of $\mathrm{NaCl}\left(24 \mathrm{~g} \mathrm{~L}^{-1}\right), \mathrm{MgCl}_{2}, 6 \mathrm{H}_{2} \mathrm{O}\left(10.8 \mathrm{~g} \mathrm{~L}^{-1}\right), \mathrm{CaCl}_{2}, 2 \mathrm{H}_{2} \mathrm{O}\left(1.5 \mathrm{~g} \mathrm{~L}^{-1}\right)$. The buffer solution $(\mathrm{pH}$ 9) was prepared with $75 \mathrm{~mL}$ of suprapur ammonia solution $25 \%$ (Merck) and 53 $\mathrm{mL}$ of suprapur hydrochloric acid $30 \%$ (Merck).

All porphyrins were commercial products (Sigma). Stock solutions of hemin $\left(1.5 \times 10^{-3} \mathrm{M}\right)$, protoporphyrin IX dimethylester $\left(10^{-3} \mathrm{M}\right)$, coproporphyrin I dihydrochloride $\left(10^{-3} \mathrm{M}\right)$, mesoporphyrin IX dihydrochloride $\left(10^{-3} \mathrm{M}\right)$ and chlorophyllin sodium copper $\left(10^{-3} \mathrm{M}\right)$ were prepared in $\mathrm{NaOH} 0.1 \mathrm{M}$ solution. Stock solutions of hemoglobin $\left(1.5 \times 10^{-2} \mathrm{M}\right)$, myoglobin $\left(1.5 \times 10^{-2} \mathrm{M}\right)$, vitamin $\mathrm{B}_{12}(0.2 \mathrm{M})$, bovine-heart cytochrome $c\left(1.5 \times 10^{-2} \mathrm{M}\right)$ and catalase $\left(1.5 \times 10^{-2} \mathrm{M}\right)$ were prepared in $\mathrm{MQ}$ water. Stock solution of horseradish peroxidase $\left(147 \mathrm{U} \mathrm{mL}^{-1}\right)$ was prepared in Tris (hydroxymethyl) aminomethane buffer $0.25 \mathrm{M}$ adjusted at $\mathrm{pH}$ 8.6. Stock solution $\left(1 \mathrm{mg} \mathrm{L}^{-1}\right)$ of chlorophyll a from Anacystis nidulans algae ( $\geq 96 \% \mathrm{HPLC}$ ) was prepared in acetone solution $90 \%$.

Stock solution of $\mathrm{Fe}^{3+}\left(1.79 \times 10^{-2} \mathrm{M}\right)$ was prepared by diluting a standard for atomic spectroscopy ( $1 \mathrm{~g}$ of $\mathrm{FeCl}_{3}$ ) (Sigma) in $100 \mathrm{~mL}$ of $\mathrm{HCl} 37 \%$ solution and completed to $1 \mathrm{~L}$ with $\mathrm{MQ}$ 
water. Stock solution of $\mathrm{Fe}^{2+}(15 \mu \mathrm{M})$ was prepared by dissolving ferrous ammonium sulfate in sulfuric acid $1 \mathrm{M}$. Stock solutions of humic acid $\left(1 \mathrm{~g} \mathrm{~L}^{-1}\right)$ was prepared in $\mathrm{NaOH} 0.1 \mathrm{M}$. Stock solutions of phytic acid $(9.12 \mu \mathrm{M})$, desferrioxamine $\mathrm{B}$ (DFOB) $(0.4 \mathrm{M})$ and $\mathrm{H}_{2} \mathrm{O}_{2}(1 \mu \mathrm{M})$ were prepared in $\mathrm{MQ}$ water. Stock solution of $\mathrm{H}_{2} \mathrm{O}_{2}$ was stored in the dark at $4^{\circ} \mathrm{C}$.

\subsection{Manifolds}

The FIA manifolds (Fig. 1) included a peristaltic pump (Gilson Minipuls 3), a six port rotary injection valve (Cheminert, model C22) and a photomultiplier (Hamamatsu, H9319-01) placed in front of a spiral cell (diameter $3.7 \mathrm{~cm}$ ). The carrier, the solutions of luminol and EDTA were pumped at flow rates of $1.2,1.2$ and $0.3 \mathrm{~mL} \mathrm{~min}^{-1}$ respectively. T-connectors, mixing coils $(0.75 \mathrm{~mm} I D$, length $96 \mathrm{~cm})$ ) and all tubings ( $0.75 \mathrm{~mm}$ ID) were made of Teflon FEP (Cluzeau Info Labo). The lengths of the tubing were: in the manifold $1,10 \mathrm{~cm}$ between the $\mathrm{T}$ connector and the input of the mixing coil and 27 $\mathrm{cm}$ between the output of the T connector and the flow cell. In the manifold 2, $10 \mathrm{~cm}$ between the first $\mathrm{T}$ connector and the input of the first mixing coil, $11 \mathrm{~cm}$ between the output of the first mixing coil and the second $\mathrm{T}$ connector, $27 \mathrm{~cm}$ between the second $\mathrm{T}$ connector and the input of the second mixing coil and $60 \mathrm{~cm}$ between the output of the second mixing coil and the flow cell. The injection loop was loaded using a $2 \mathrm{~mL}$ plastic syringe.

\subsection{Procedure for determination of Fe-Py}

All the solutions containing porphyrin were manipulated at low ambient light level and using opaque polyethylene bottles to avoid photo-degradation of the complexes. The concentrations of FePy-like complexes were determined by standard additions of hemin in the samples. Thus the unit of the concentrations of Fe-Py-like complexes was nM of equivalent hemin.

The manifold \#1 was used to analyse Fe-Py complexes in $\mathrm{NaOH}$, in artificial and natural seawater, the $\mathrm{pH}$ of the sample $(3.5 \mathrm{~mL})$ was buffered to $\mathrm{pH}=9$ with $980 \mu \mathrm{L}$ of buffer solution, followed by the addition of $420 \mu \mathrm{L}$ of EDTA. Finally, the $\mathrm{pH}$ of the sample was increased up to 13 by addition of $210 \mu \mathrm{L}$ of $\mathrm{NaOH} 8 \mathrm{M}$.

The manifold \#2 was used for direct injection of samples of artificial seawater, natural waters (sea, river and pond waters) and culture media.

\subsection{Study of interference}

Possible interferences of inorganic $\left(\mathrm{Fe}^{3+}, \mathrm{Fe}^{2+}, \mathrm{Cu}^{2+}, \mathrm{Co}^{2+}\right.$ and $\mathrm{H}_{2} \mathrm{O}_{2}$ ) and organic (DFOB, FeDFOB, humic and phytic acids) species were investigated. The samples were analysed by standard additions of hemin, immediately after the addition of the interferent. The effect of humic acids was studied in $\mathrm{NaOH}$, because humic acid is more soluble at high $\mathrm{pH}$. All other interferents were tested in seawater. In the case of phytic acid and $\mathrm{H}_{2} \mathrm{O}_{2}$, two other experiments were performed where the interferent was first equilibrated with the sample for $12 \mathrm{~h}$ and $30 \mathrm{~min}$ respectively following by standard addition analysis.

\subsection{Sampling of natural surface waters}

Oceanic water was collected using GoFlo bottles during the KEOPS cruise in the Southern Ocean. Samples were also collected in the Rhône river (France) in the mouth of the Kourou river (Guyana, France) in the pond of Berre (France).

All samples were immediately filtered after sampling through polycarbonate filters $(0.2 \mu \mathrm{m})$. The oceanic samples were analysed on board, immediately after sampling or after few days of storage at $4^{\circ} \mathrm{C}$. The river samples were stored at $4^{\circ} \mathrm{C}$, and analysed few days later in the laboratory.

\subsection{Culture experiments}

Green marine alga Dunaliella tertiolecta was supplied by CSIRO (strain CS-175 of Dunaliella tertiolecta). The culture media was a $\mathrm{f} / 2$ medium $\left[{ }^{30},{ }^{31}\right]$ modified as follow: filtered Mediterranean seawater $(0.2 \mu \mathrm{m})$ was enriched with $\mathrm{NaNO}_{3}\left(75 \mathrm{mg} \mathrm{L}^{-1}\right), \mathrm{NaH}_{2} \mathrm{PO}_{4}\left(4.4 \mathrm{mg} \mathrm{L}^{-1}\right), \mathrm{CoCl}_{2}, 6 \mathrm{H}_{2} \mathrm{O}\left(10 \mu \mathrm{g} \mathrm{L}^{-}\right.$ $\left.{ }^{1}\right), \mathrm{MnCl}_{2}, 4 \mathrm{H}_{2} \mathrm{O}\left(180 \mu \mathrm{g} \mathrm{L}^{-1}\right), \mathrm{CuSO}_{4}, 5 \mathrm{H}_{2} \mathrm{O}\left(9.8 \mu \mathrm{g} \mathrm{L}^{-1}\right), \mathrm{ZnSO}_{4}, 7 \mathrm{H}_{2} \mathrm{O}\left(22 \mu \mathrm{g} \mathrm{L}{ }^{-1}\right), \mathrm{NaMoO}_{4}, 2 \mathrm{H}_{2} \mathrm{O}(6.3$ $\left.\mu \mathrm{g} \mathrm{L}^{-1}\right), \mathrm{FeCl}_{3}, 6 \mathrm{H}_{2} \mathrm{O}\left(315 \mathrm{ng} \mathrm{L}{ }^{-1}\right), \mathrm{Na}_{2}$ EDTA $\left(436 \mathrm{ng} \mathrm{L}{ }^{-1}\right)$, thiamine, cyanocobalamine (vitamin $\left.\mathrm{B}_{12}\right)$ and biotine. The sterilization of the medium was performed by autoclaving at $120^{\circ} \mathrm{C}$ for $20 \mathrm{~min}$, except for the vitamin solution, which was added after sterilization by filtration $(0.2 \mu \mathrm{m})$. Cultures were grown at 
ambient temperature under natural light conditions. The bottles were shaken once daily by hand. $A$ flow cytometer (Cytoron Absolute, Ortho Diagnostic Systems, France) was used for cell counting.

For the determination of the intracellular content of Fe-Py more than 1000 cells $\mu \mathrm{L}^{-1}$ were collected on polycarbonate filters $(0.2 \mu \mathrm{m})$. The cells were then broken by placing the filters in $30 \mathrm{~mL}$ of $\mathrm{NaOH}(0.1 \mathrm{M})$ during $15 \mathrm{~min}$ with magnetic stirring. The mixture was then filtered $(0.2 \mu \mathrm{m})$ to eliminate the broken cells.

\section{Results and discussion}

\subsection{Mechanims of the reaction}

The mechanism of the non-peroxidative chemiluminescence of luminol has been studied in detail $\left[{ }^{32,33}\right]$. This mechanism includes two different steps of oxidation (Fig. 2). The primary (one electron) oxidation can be achieved by many strong oxidants and leads to the luminol radical which exist as undissociated form ( $\mathrm{LH}^{\circ}$ ) or as monoanion $\mathrm{L}^{\circ}$ - depending on the $\mathrm{pH}$. Two different pathways are possible for the secondary oxidation leading to the $\alpha$-hydroxy-hyperoxide ( $\alpha$-HPP) which produces luminescence by decomposition to aminophthalate. The direct oxidation by superoxide (reaction 1 , Fig. 2) can only occurs with the monoanion $L^{\circ}$. The second pathway involves the oxidation of the luminol radical to diazoquinone $L$ (reaction $2 \mathrm{a}$, Fig. 2) and the subsequent oxidation by the monodissociated hydrogen peroxide (reaction $2 \mathrm{~b}$, Fig. 2). The importance of the different pathways has be discussed in detail by Rose and Waite $\left.{ }^{33}\right]$ in the case of the determination of $\mathrm{Fe}(\mathrm{II})$ by chemiluminescence. They show that $\mathrm{OH}^{\circ}$ and $\mathrm{O}_{2}{ }^{\circ-}$ are the oxidants involved in the primary oxidation of the luminol and that the secondary oxidation proceeds via the direct oxidation of the luminol radical by $\mathrm{O}_{2}{ }^{\circ}$. All the reactions occur within the cell in roughly one second.

The mechanism for the non-peroxidative chemiluminescence of luminol in presence of Fe-Py is not established. However based on the reactions describe above and considering the conditions used in the $\mathrm{FePy}-\mathrm{O}_{2}$-luminol system a possible mechanism can be suggested. The $\mathrm{pH}$ of 13 used in the reaction implies that the luminol is present as a dianion. The one electron oxidation results in the luminol radical present as monoanion $\left(\mathrm{Ka}=2 \times 10^{-8}\left[{ }^{34}\right]\right)$. If we consider that $\mathrm{O}_{2}{ }^{0^{-}}$is not initially present in the solution of Fe-Py, the secondary oxidation step will require an in situ production of $\mathrm{O}_{2}{ }^{-}$. It has been reported that $\mathrm{L}^{\circ-}$ can react with $\mathrm{O}_{2}$ to produce $\mathrm{O}_{2}{ }^{\circ-}$ and $\mathrm{L}$. Because $\mathrm{L}$ is rapidly hydrolysed ${ }^{35}$ ] all $\mathrm{L}^{\circ-}$ that react with $\mathrm{O}_{2}$ should produce $\mathrm{O}_{2}{ }^{\circ-}$. This reaction is slow compared to other reactions involved in the mechanism $\left.{ }^{[3}\right]$. Some characteristics of the method presented in the section below are discussed in the light of this possible mechanism.

\subsection{Implementation in a flow injection manifold}

The chemiluminescent reaction described by Motsenbocker and co-workers $\left[{ }^{28}\right]$ was implemented into the FIA manifold \#1 (Fig. 1a). The carrier stream of $\mathrm{NaOH}(0.1 \mathrm{M})$ was mixed with luminol $(1.5 \mathrm{mM}, \mathrm{pH} 13)$ within a knitted mixing coil before passing through the detector. The internal diameter of the mixing coil was of $0.75 \mathrm{~mm}$ and the length was of $90 \mathrm{~mm}$ resulting in the residence time of 20s. The manifold was tested using solutions of hemin in $\mathrm{NaOH} 0.1 \mathrm{M}$.

Additions of hemin were realised in $\mathrm{NaOH}$ and the standards were immediately injected. The calibration curve based on the integrated signal was linear $(y=a(F e-P y)+b$ with $a=1.83 \pm 0.05 ; b=$ $0.44 \pm 0.05 ; r^{2}=0.99$ ). The signal of a solution containing $4 \mathrm{nM}$ of hemin was stable during $4 \mathrm{~h}$ after its preparation. The limit of detection ( 3 time the standard deviation of the blank, $\mathrm{n}=10$ ) was $0.38 \mathrm{nM}$.

\subsection{The case of seawater}

Direct injection of seawater in manifold \#1 was not possible due to the precipitation of magnesium and calcium hydroxyde that would rapidly clog up the tubing. The precipitation was masked by complexing $\mathrm{Ca}^{2+}$ and $\mathrm{Mg}^{2+}$ with EDTA before mixing the seawater with $\mathrm{NaOH}$. This procedure was first tested off line.

The stability of the treated seawater sample over the time was investigated. The signal of natural seawater spiked with $4 \mathrm{nM}$ of hemin decreased significantly $(50 \%)$ after $5 \mathrm{~h}$. This could be due to the slow exchange of Fe contained in hemin with free EDTA (see below). This decrease may also be caused by a slow exchange with natural ligands present in seawater. In this case, the decrease would depend on the type and on the concentrations of ligands and therefore would be different for different samples. Whatever the cause, the decrease of the signal with time reduced the sensitivity of 
the method. Therefore the sample must be injected immediately after being treated. The typical time lag between the beginning of the treatment and the injection was roughly 1 min.

To improve the reproducibility, EDTA was then added on-line. The manifold \#1 was modified as shown in Figure 1b. The $\mathrm{pH}$ of luminol was increased to keep an optimum $\mathrm{pH}$ of 13 before the mixing coil. The carrier $(\mathrm{NaOH} 0.1 \mathrm{M})$ used with the manifold $\# 1$ was not appropriate to the manifold \#2 because the injection of seawater would have precipitated hydroxide. Different carriers (MQ water; $\mathrm{NaCl}(0.5 \mathrm{M})$ and artificial seawater) were tested. The signals resulting from the injection of seawater in these different carriers are shown in Figure 3. Injection in MQ water produced an asymmetric peak, probably due to the strong difference in ionic strength between the sample and the carrier. $\mathrm{NaCl}$ and the artificial seawater produced better peaks. $\mathrm{NaCl}$ was chosen because it gave a better sensitivity and was easier to prepare than artificial seawater.

\subsection{Competition with EDTA}

EDTA is a good ligand for iron, thus adding EDTA as masking agent of the precipitation of $\mathrm{Ca}^{2+}$ and $\mathrm{Mg}^{2+}$, could also reduce the concentration of iron complexes initially present in the sample. Different concentrations of EDTA $(0.125 \mathrm{M}, 0.25 \mathrm{M}, 0.375 \mathrm{M}, 0.5 \mathrm{M}, 0.675 \mathrm{M})$ were tested with seawater spiked with $6 \mathrm{nM}$ of hemin and seawater without hemin addition. The precipitation of hydroxide was observed at the outlet of the mixing coil when the lowest concentration of EDTA was used. Concentrations of $0.5 \mathrm{M}$ and higher resulted in saturation of the EDTA solution. For the other concentrations of EDTA no significant change in the signal was observed. Therefore we conclude that EDTA, at the concentration required to mask the precipitation of $\mathrm{Ca}^{2+}$ and $\mathrm{Mg}^{2+}$, does not interfere with the Fe-Py determination.

\subsection{Optimization of the method}

The effect of the time of mixing between the sample and the luminol was investigated by varying the length of the mixing coil in manifold \#2. Different times of mixing (15s, 20s and 40s) gave the same sensitivity.

The $\mathrm{FePy}-\mathrm{O}_{2}$-luminol chemiluminescence is observed after $15 \mathrm{~s}$ and the signal does not change significantly when the mixing time was increased to 20 and 40s. This is consistent with a steady state concentration $\mathrm{O}_{2}{ }^{0-}$ resulting from the production by reaction 1 and consumption by the reaction 2. In the $\mathrm{Fe}(\mathrm{II})-\mathrm{O}_{2}$-luminol chemiluminescence, Waite and Rose $\left[{ }^{33}\right]$ have demonstrated that different levels of impurities in the luminol reagent result in steady state concentration of $\mathrm{L}^{\circ-}$ and $\mathrm{O}_{2}{ }^{\mathrm{o}^{-}}$in the range of $40 \mathrm{~s}-3$ months.

Merényi suggested that the role of the superoxide can be ascertained by the addition of superoxodismutase (SOD), which catalyses the dismutation of $\mathrm{O}_{2}{ }^{\circ-}$ with the production of hydrogen peroxide [32]. The addition of $1.2 \mathrm{mg} \mathrm{L}^{-1}$ of SOD in hemin standard solution decreases the chemiluminesence by $45 \%$. The only partial reduction of the signal might be due to the decrease in the activity of the SOD at high $\mathrm{pH}\left[{ }^{36}\right]$.

The influence of temperature was also tested by placing the reaction coil (e) in a thermo insulated water bath. The signal obtained at 30 and $40{ }^{\circ} \mathrm{C}$ did not differ significantly from the signal measured at ambient temperature. The signal increased by $20 \%$ when the temperature was set to $50^{\circ} \mathrm{C}$.

Therefore the optimised conditions were a mixing time of $20 \mathrm{~s}$ at $50^{\circ} \mathrm{C}$. The calibration curve of hemin in seawater was linear $(y=3,6782$ (FePy $)+1,1605$ avec $\left.r^{2}=0,9861\right)$ in the range of concentrations $0-7.5 \mathrm{nM}$. The limit of detection of the method was $0.11 \mathrm{nM}$ ( 3 time the standard deviation of the blank, $n=10$ ).

\subsection{Selectivity of the method}

The feasibility of the determination of Fe-Py-like complexes in seawater is demonstrated using hemin as a model. However, in natural waters other Fe-Py-like complexes as well as free porphyrin or porphyrin complexed with metal other than iron may be present. We have tested our method with commercially available porphyrins. The results are summarised in Table 1. The injection of metal free porphyrins (proto-, meso- and copro-porphyrins), magnesium-porphyrin (chlorophyll a), copperporphyrin (chlorophyllin) and cobalt-porphyrin (vitamin $\mathrm{B}_{12}$ ) did not give a significant signal compared to injection of hemin at the same concentration. The catalase, an enzyme containing 4 Fe-Py units, had a similar response to hemin. A signal enhanced by a factor of 3 compared to hemin was obtained with the peroxidase, an enzyme containing $1 \mathrm{Fe}-\mathrm{Py}$ unit and with the cytochrome $c$, a macromolecule 
containing 2 Fe-Py units. The highest responses (x 12 and $x 15)$ relative to hemin were obtained with myoglobin (1 Fe-Py unit) and hemoglobin (4 Fe-Py units) respectively.

The number of porphyrins tested in this work is limited, but the results show that the method is quite selective for the detection of Fe-Py-like complexes. However, the sensitivity of the signal is dependent of the nature of the Fe-Py complexes. Previous work determining porphyrins for immunoassay development and using the same chemical reaction have shown that a synthetic $\mathrm{Mn}$ porphyrin complex also produced a chemiluminescent signal $\left[{ }^{28}\right]$ and therefore our method could occasionally detect non Fe-porphyrin. However, the number of Mn-Py complexes biosynthesized in organisms (i.e. Mn-peroxidase) is well below the number of Fe-Py. They are probably not abundant in natural waters compared to Fe-Py.

When natural samples are analysed, the exact nature of the Fe-Py complexes contained in the sample is not known. The sample contains very likely a mixture of different Fe-Py complexes, which give different chemiluminescent signals when separately injected in our manifold. The concentration of Fe-Py-like complexes determined by our method must be interpreted as a concentration of species in the sample that gives a signal corresponding to the same concentration of hemin. So, the correct unit to be used is nM eq. hemin.

\subsection{Interferences}

The results of the study of the interferences are reported in Table 2. These chemical species were selected because they are known to produce a chemiluminescent signal in the $\mathrm{O}_{2}$-luminol reaction $\left[{ }^{26,37}\right]$ or because they can react with $\mathrm{Fe}-\mathrm{Py}$ (for example $\mathrm{H}_{2} \mathrm{O}_{2}$ with catalase and peroxidase). In the case of $\mathrm{H}_{2} \mathrm{O}_{2}$ we suggest that the rapid hydrolyse at $\mathrm{pH} 13$ of $\mathrm{L}$ by $\mathrm{OH}^{-}$does not allow the formation of the $\alpha$-HPP by the reaction $2 b$ (Fig. 2) and therefore the presence of $\mathrm{H}_{2} \mathrm{O}_{2}$ does not interfere with the determination of Fe-Py. The absence of interference with $\mathrm{Fe}^{2+}, \mathrm{Cu}^{2+}$ and $\mathrm{Co}^{2+}$ results likely from non-optimum $\mathrm{pH}$ conditions. In fact the non-peroxidative chemiluminescence with these metals required the $\mathrm{pH}$ to be 3 units lower than in our method. In addition the chemiluminescence resulting from these metals is produced within the seconds following the mixing between the metal and the luminol $\left[{ }^{23,37}\right]$. Therefore most of this signal has disappeared before entering in the flow cell of our manifold. For $\mathrm{Fe}^{3+}, \mathrm{H}_{2} \mathrm{O}_{2}$ is required to produce the chemiluminescence $\left[{ }^{19}\right]$. The levels of $\mathrm{H}_{2} \mathrm{O}_{2}$ in natural samples are too low compared to the typical concentrations of $\mathrm{H}_{2} \mathrm{O}_{2}\left(0.1 \mathrm{M}-0.7 \mathrm{M}\right.$ used in Fe ${ }^{3+}$ chemiluminescent method $\left[{ }^{19,21}\right]$.

DFOB (free and complexed), humic and phytic acids were tested because they are models of possible natural organic ligands for iron $\left[{ }^{38,}{ }^{39}\right]$. The exchange of iron between hemin and natural ligands might change the sensitivity of the method. This was not observed for the ligands tested in this study. The important role of $\mathrm{O}_{2}{ }^{\circ}$ in the mechanism of the detection reaction (Fig. 2) implies that this specie is a possible interferent in the determination of Fe-Py. Superoxide is inherently unstable but the continuous production of $\mathrm{O}_{2}{ }^{\circ-}$ can lead to steady state concentration. For example extracellular release of superoxide by phytoplankton with detectable superoxide concentrations in the culture media has been reported $\left[{ }^{40,41}\right]$. Photochemical reactions of dissolved organic matter can also produce superoxide $\left[{ }^{42}\right]$. Because SOD does not fully inhibit the non peroxidative luminol reaction at $\mathrm{pH} 13$ (see above), the addition of SOD in the sample at its natural pH (around 8 for seawater) can be use to eliminate the interference. Kustka et al. have reported that the addition of $10 \mathrm{U}$ per $3 \mathrm{ml}$ was enough to decrease the superoxide concentration by $95 \%\left[{ }^{41}\right]$. This concentration of SOD reduces only by $14 \%$ the signal produced by a standard containing $3.5 \mathrm{nM}$ of hemin

None of the tested chemical species, with concentration similar to those expected in seawater gave strong interference. However, because the slope of the calibration curve is dependent on the nature of the sample, standard additions are definitively required.

\subsection{Storage of samples}

The stability of the samples during storage was studied using water collected in the Rhône river. Different conditions of storage were tested: $(i)$ the storage protocol used for iron binding ligand studies $\left[{ }^{10}\right]$, where the sample is immediately filtered after sampling and stored at ambient temperature or frozen (ii) the sample is poisoned with $\mathrm{HgCl}_{2}$ stored at ambient temperature or frozen. The filtration is carried out just before analysis.

Figure 4 shows the evolution of Fe-Py concentrations as a function of time when samples are filtered immediately after sampling and then stored at ambient temperature (Fig. 4a) or frozen (Fig. 4b). At ambient temperature, Fe-Py concentrations decreased from day 1 to day 23 and then increased from day 23 to day 48. The concentration in frozen samples decreased also between day 1 
and day 23 but remained constant for the next 20 days. Biological activity (bacteria and viruses) as well as abiotic processes like aggregation-desegregation or desorption-adsorption could be responsible for the lack of stability of the sample but the exact causes of these changes remain unknown. In order to improve the storage protocol we have stored unfiltered samples poisoned with $\mathrm{HgCl}_{2}$. This protocol precludes biological activity and does not modify the initial speciation of the sample especially the balance between particles and dissolved species. The results are shown in Figure 5. Despite some variability, the concentration in the samples was stable during 15 days whatever the temperature of storage. At ambient temperature, a slight decrease was observed 39 days after sampling. This was not the case with the frozen samples.

\subsection{Applications}

\subsubsection{Culture experiments}

The aim of this experiment was to demonstrate that our analytical method could detect Fe-Py complexes like those biosynthesised by phytoplankton. During our culture experiment, carried out in duplicate, we determined intracellular content of Fe-Py-like complexes of $1.0 \times 10^{-18}$ and $5.0 \times 10^{-18}$ mol of equivalent hemin per cell. The exact amount of this kind of complexes within phytoplankton is not known accurately but it can be roughly estimated. The iron content of cells growing under non Fe limiting conditions was reported to be around $10^{-16} \mathrm{~mol} \mathrm{Fe} \mathrm{cell}{ }^{-1}\left[{ }^{43}\right]$. Only one third of the atom $\left(3 \times 10^{-17} \mathrm{~mol} \mathrm{cell}^{-1}\right)$ is likely associated with iron-protein $\left[{ }^{44}\right]$. Considering that Fe-Py protein are a fraction of the iron protein we found this number is likely an upper limit. For bacteria, direct measurements of hemeprotein (catalase or cytochrome $c$ ) have been reported in the range $10^{-19}-10^{-20} \mathrm{~mol} \mathrm{cell}^{-1}\left[{ }^{45,}{ }^{46}\right]$. Therefore our measurements of the intracellular content of Fe-Py fall in this range. Recently, a new HPLC - spectrophotometric method for the direct determination of heme $b$ content of planktonic organisms was reported $\left[{ }^{47}\right]$. In this study, the intracellular content of heme $b$ of Dunaliella tertiolecta was of $2.41 \mathrm{nmol} \mathrm{L}^{-1}$ with a cell abundance of $18 \times 10^{7}$ cell L $^{-1}$. The intracellular quota is therefore of $1.34 \times 10^{-17}$ mole heme $b$ cell $^{-1}$. For the same phytoplankton we found a cellular quota in the range of $1-5 \times 10^{-18}$ mol FePy cell $^{-1}$. The agreement is good considering that the cellular quota very likely depend on the conditions (light, nutrient) prevailing during the culture. This comparison confirms that the FIA chemiluminescent method is a valuable tool for measuring Fe-Py-like complexes produced by living organisms.

\subsubsection{Determination in natural waters}

We have also applied the method to a few natural waters with different salinity. The results are summarised in Table 4. Fe-Py-like complexes were not detectable in the samples coming from the surface water of the Southern Ocean. Dissolved iron concentration, that includes all the dissolved organic and inorganic forms of iron, did not exceed $0.3 \mathrm{nM}$ (Blain et al. in prep). If Fe-Py were present in the sample, it could only be a fraction of $0.3 \mathrm{nM}$. Thus the concentration of Fe-Py-like was below the limit of detection of our method. A pre-concentration step will be required for analysing open ocean waters. However in pond and river waters, signal corresponding to $8 \mathrm{nM}$ equivalents of hemin were measured. These results are encouraging because they indicate that Fe-Py might be present in natural waters with high iron and high organic matter contents.

\section{Conclusions}

This work presents the first FIA method for determining of Fe-Py-like complexes in natural waters. The complexes can be detected at the nanomolar levels without any major interferences. It will allow further studies of the biogeochemistry of these complexes in natural waters and represent a step forward to a better knowledge of iron speciation in aquatic environments.

\section{Acknowledgements}

This work was supported by INSU CNRS. We thank E. Gouze and P. Raimbault for providing the samples from étang de Berre and Rhone. 


\section{References}

[1] Martin, J. H. Primary Productivity and Biogeochemical Cycles in the Sea 1992, 123-137.

[2] de Baar, H. J. W.; Boyd, P. W.; Coale, K. H.; Landry, M. R.; Tsuda, A.; Assmy, P.; Bakker, D. C. E.; Bozec, Y.; Barber, R. T.; Brzezinski, M. A.; Buesseler, K. O.; Boye, M.; Croot, P. L.; Gervais, F.; Gorbunov, M. Y.; Harrison, P. J.; Hiscock, W. T.; Laan, P.; Lancelot, C.; Law, C. S.; Levasseur, M.; Marchetti, A.; Millero, F. J.; Nishioka, J.; Nojiri, Y.; van Oijen, T.; Riebesell, U.; Rijkenberg, M. A.; Saito, H.; Takeda, S.; Timmermans, K. R.; Velduis, M. J. W.; Waite, A. M.; Wong, C. S. Journal of Geophysical Research 2005, 110, 1-24.

[3] Croot, P. L.; Johansson, M. Electroanalysis 2000, 12, 565-576.

[4] Gledhill, M.; van den Berg, C. M. G. Marine Chemistry 1994, 47, 41-54.

[5] Rue, E. L.; Bruland, K. W. Marine Chemistry 1995, 50, 117-138.

[6] Wu, J.; Luther III, G. W. Marine Chemistry 1995, 50, 159-177.

[7] Gledhill, M.; van den Berg, C. M. G.; Nolting, R. F.; Timmermans, K. R. Marine Chemistry 1998, 59, 283-300.

[8] Witter, A. E.; Luther III, G. W. Marine Chemistry 1998, 62, 241-258.

[9] Rue, E. L.; Bruland, K. W. Limnology and Oceanography 1997, 42, 901-910.

[10] van den Berg, C. M. G. Marine Chemistry 1995, 50, 139-157.

[11] Witter, A.; Lewis, B. L.; Luther III, G. W. Deep-Sea Research I/ 2000, 47, 1517-1539.

[12] Granger, J.; Price, N. M. Limnology and Oceanography 1999, 44, 541-555.

[13] Wilhelm, S. W.; Trick, C. G. Limnology and Oceanography 1994, 39, 1979-1984.

[14] Kilz, S.; Lenz, C.; Budzikiewicz, H. Journal of Mass Spectrometry 1999, 34, 281-290.

[15] Gledhill, M. The Analyst 2001, 126, 1359-1362.

[16] McCormack, P.; Worsfold, P. J.; Gledhill, M. Analytical Chemistry 2003, 2647-2652.

[17] Caughey, W. S. Annual Review of Biochemistry 1967, 36, 611-644.

[18] Fletcher, P.; Andrew, K. N.; Calokerinos, A. C.; Forbes, S.; Worsfold, P. J. Luminescence 2001, 16, 1-23.

[19] Obata, H.; Karatani, H.; Nakayama, E. Analytical Chemistry 1993, 65, 1524-1528.

[20] Obata, H.; Karatani, H.; Matsui, M.; Nakayama, E. Marine Chemistry 1997, 56, 97-106.

[21] de Jong, J. T. M.; den Das, J.; Bathmann, U.; Stoll, M. H. C.; Kattner, G.; Nolting, R. F.; de Baar, H. J. W. Analytica Chimica Acta 1998, 377, 113-124.

[22] Seitz, W. R.; Hercules, D. M. Analytical Chemistry 1972, 44, 2143-2149.

[23] King, D. W.; Lounsbury, H. A.; Millero, F. J. Environmental Science and Technology 1995, 29, 818-824.

[24] O'Sullivan, D. W.; Hanson, A. K.; Kester, D. R. Marine Chemistry 1995, 49, 65-77.

[25] Powell, R. T.; King, D. W.; Landing, W. M. Marine Chemistry 1995, 50, 13-20.

[26] Bowie, A. R.; Achterberg, E. P.; Fauzi, R.; Mantoura, C.; Worsfold, P. J. Analytica Chimica Acta 1998, 361, 189-200.

[27] Ussher, S. J.; Yaqoob, M.; Achterberg, E. P.; Nabi, A.; Worsfold, P. J. Analytical Chemistry 2005, 77, 1971-1978.

[28] Motsenbocker, M.; Ichimori, Y.; Kondo, K. Analytical Chemistry 1993, 65, 397-402.

[29] Song, Z.; Wang, L.; Hou, S. Analytical and Bioanalytical Chemistry 2004, 378, 529-535.

[30] Guillard, R. R. L.; Ryther, J. H. Canadian Journal of Microbiology 1962, 8, 229-239.

[31] Guillard, R. R. L. Culture of phytoplankton for feeding marine invertebrates; Plenum Press: New York, 1975.

[32] Merényi, G.; Lind, J.; Eriksen, T. E. Journal of Bioluminescence and Chemiluminescence 1990, 5, 53-56.

[33] Rose, A. L.; Waite, T. D. Analytical Chemistry 2001, 73, 5909-5920.

[34] Merényi, G.; Lind, J. In 5th symposium on radiation chemistry 1983, 103-108.

[35] Lind, J.; Merényi, G.; Eriksen, T. E. Journal of the American Chemical Society 1983, 105, 7655-7661.

[36] O'neill, P.; Davies, S.; Fielden, E. M.; Calabrese, L.; Capo, C.; Marmocchi, F.; Natoli, G.; Rotilio, G. Biochemical Journal 1988, 251, 41-46.

[37] Klopf, L. L.; Nieman, T. A. Analytical Chemistry 1983, 55, 1080-1083.

[38] Buffle, J.; Greter, F. L.; Haerdi, W. Analytical Chemistry 1977, 49, 216-222.

[39] Witter, A.; Hutchins, D. A.; Butler, A.; Luther III, G. W. Marine Chemistry 2000, 69, 1-17.

[40] Marshall, J. A.; de Salas, M.; Oda, T.; Hallegraeff, G. Marine Biology 2005, 541-549.

[41] Kustka, A. B.; Shaked, Y.; Milligan, A. J.; King, D. W.; Morel, F. M. M. Limnology and Oceanography 2005, 50, 1172-1180. 
[42] Rose, A. L.; Waite, A. Environmental Science and Technology 2005, 39, 2645-2650.

[43] Hudson, R. J. M.; Morel, F. M. M. Limnology and Oceanography 1990, 35, 1002-1020.

[44] Raven, J. A. New Phytologist 1988, 109, 279-287.

[45] Miller, C. A.; Vogelhut, P. Applied and Environmental Microbiology 1978, 35, 813-816.

[46] Ewetz, L.; Thore, A. Applied and Environmental Microbiology 1978, 36, 790-793.

[47] Gledhill, M. Marine Chemistry 2007, 103, 393. 
Table 1: Comparison of the chemiluminescent signal produced by different porphyrin and metalporphyrin complexes

\begin{tabular}{|c|c|c|c|}
\hline Central metal atom & Compounds & $\begin{array}{l}\text { Range of concentrations } \\
(\mathrm{nM})\end{array}$ & $\begin{array}{l}\text { Relative signal to } \\
\text { hemin }\end{array}$ \\
\hline- & Protoporphyrin IX & $0-7.5 \mathrm{nM}$ & 0.17 \\
\hline- & Mesoporphyrin & $0-7.5 \mathrm{nM}$ & 0.05 \\
\hline- & Coproporphyrin & $0-7.5 \mathrm{nM}$ & 0.05 \\
\hline $\mathrm{Mg}$ & Chlorophyll a & $0-280 \mathrm{nM}$ & 0.01 \\
\hline $\mathrm{Cu}$ & Chlorophyllin & $0-\quad 4 \mathrm{nM}$ & 0.05 \\
\hline Co & Vitamin $B_{12}$ & $0-140 \mathrm{nM}$ & 0.07 \\
\hline $\mathrm{Fe}$ & Hemin & $0-7.5 \mathrm{nM}$ & 1 \\
\hline $\mathrm{Fe}$ & Catalase & $0-7.5 \mathrm{nM}$ & 1.54 \\
\hline $\mathrm{Fe}$ & Cytochrome $c$ & $0-7.5 \mathrm{nM}$ & 3.26 \\
\hline $\mathrm{Fe}$ & \multicolumn{2}{|c|}{ Horseradish peroxidase $0-7.5 \mathrm{nM}$} & 3.35 \\
\hline $\mathrm{Fe}$ & Myoglobin & $0-7.5 \mathrm{nM}$ & 12.36 \\
\hline $\mathrm{Fe}$ & Hemoglobin & $0-7.5 \mathrm{nM}$ & 15.07 \\
\hline
\end{tabular}


Table 2: Interferences in the Fe-Py determination

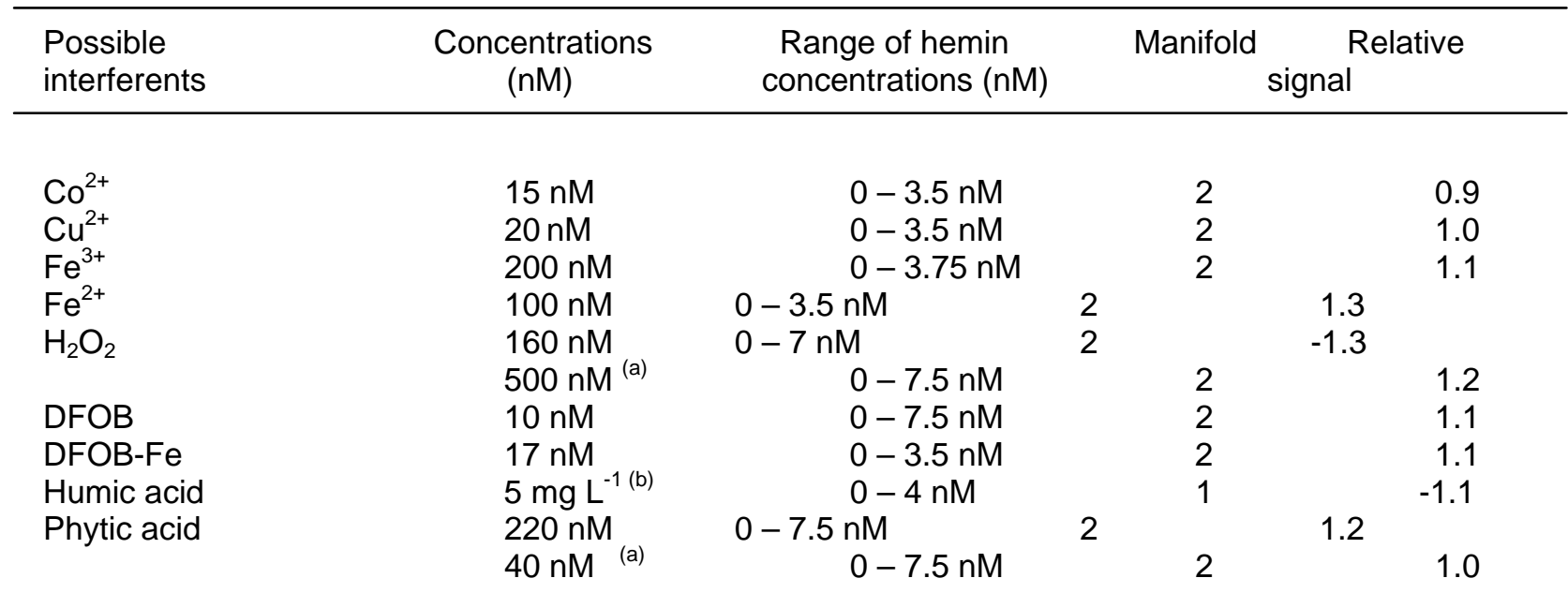

(a) Previously equilibrated with the sample before injection. See method

(b) Corresponding to $617 \mu$ moles carbon $\mathrm{L}^{-1}$ 
Table 3: Fe-Py concentrations in natural waters

\begin{tabular}{llc}
\hline Sampling site & Salinity & $\begin{array}{c}\text { Concentrations of Fe-Py } \\
\text { (nM of equivalent hemin) }\end{array}$ \\
\hline Austral ocean & 33.8 & under LD \\
Guiana & {$[30-34]$} & $2.1 \pm 0.4$ \\
Berre & 22 & $11.5 \pm 1.3$ \\
Rhône & 0 & $9.2 \pm 0.9$
\end{tabular}


Manifold 1

$N^{(a)}$

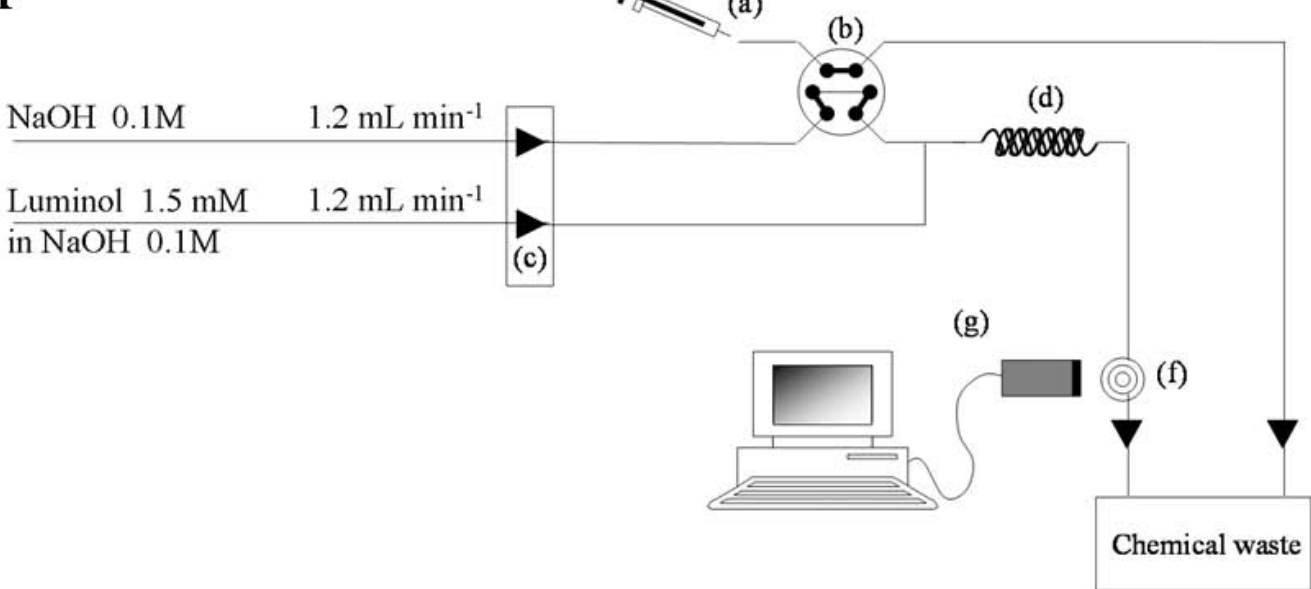

Manifold 2

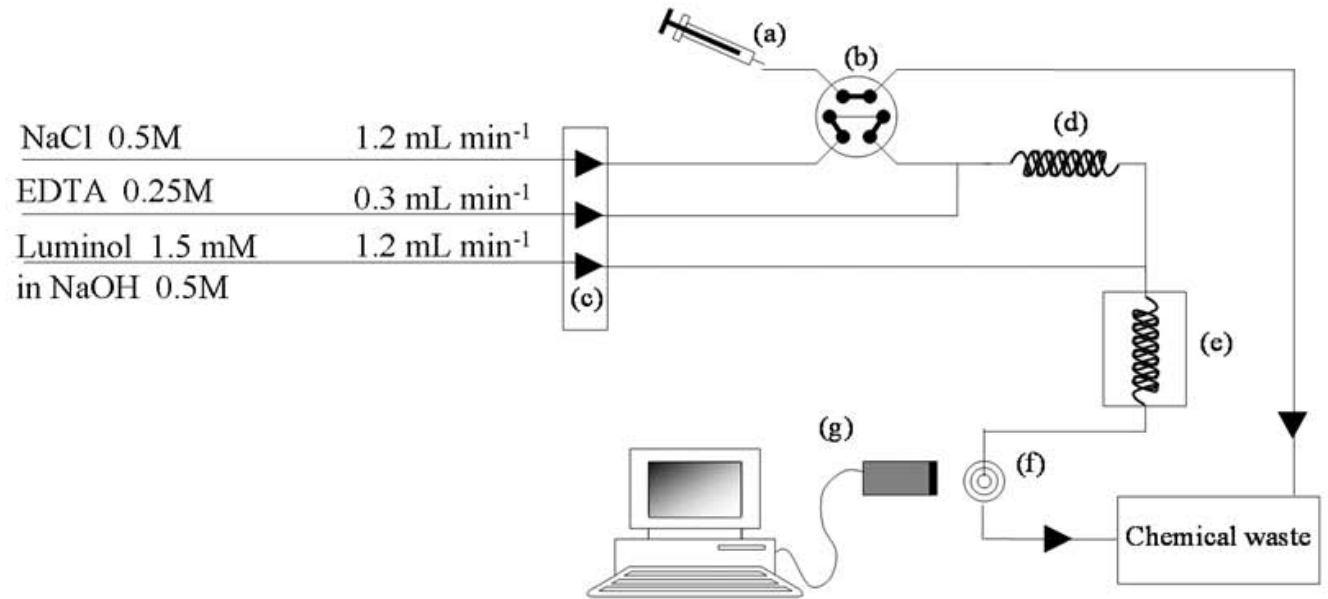

Figure 1: Flow injection manifolds: (a) syringe, (b) six-port rotary valve, (c) peristaltic pump, (d) mixing coil, (e) thermo insulated bath (f) flow cell, (g) photomultiplier. 


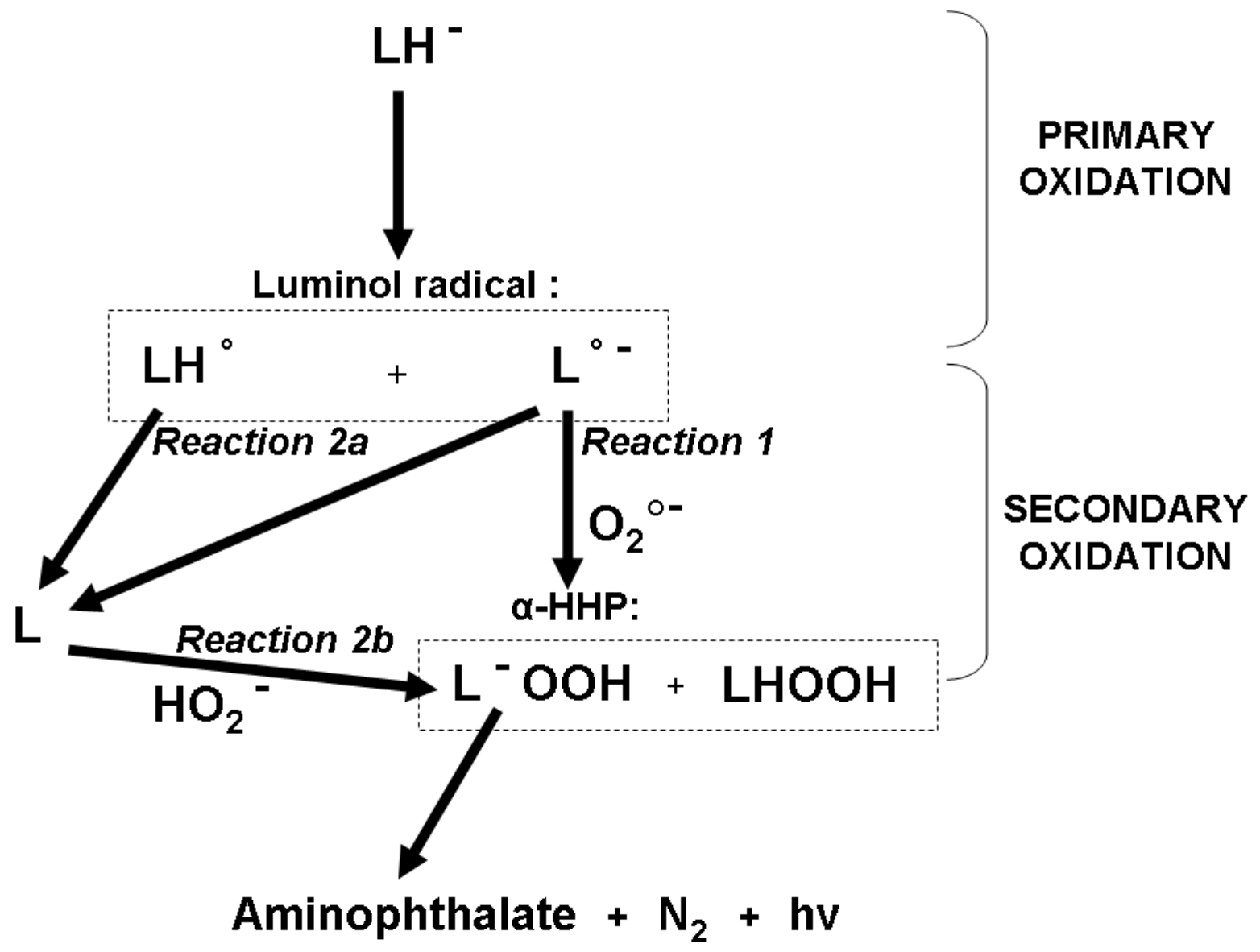

Figure 2: Mechanisms of luminol oxidation for Fe(II) chemistry, adapted from Merényi and co-workers $\left[{ }^{32}\right]$ and Rose and Waite $\left.{ }^{33}\right]$. $\mathrm{LH}^{-}=$luminol; $\mathrm{LH}^{\circ}=$ undissociated form of luminol radical; $\mathrm{L}^{0^{-}}=$ monoanion form of luminol radical; $\mathrm{L}=$ Diazoquinone; $\alpha$-HHP $=$ a-hydroxy-hydroperoxide; $\mathrm{L}^{-} \mathrm{OOH}=$ monoanion form of $\alpha-\mathrm{HHP} ; \mathrm{LHOOH}=$ undissociated form of $\alpha-\mathrm{HHP} ; \mathrm{O}_{2}{ }^{{ }^{-}}=$superoxide. 


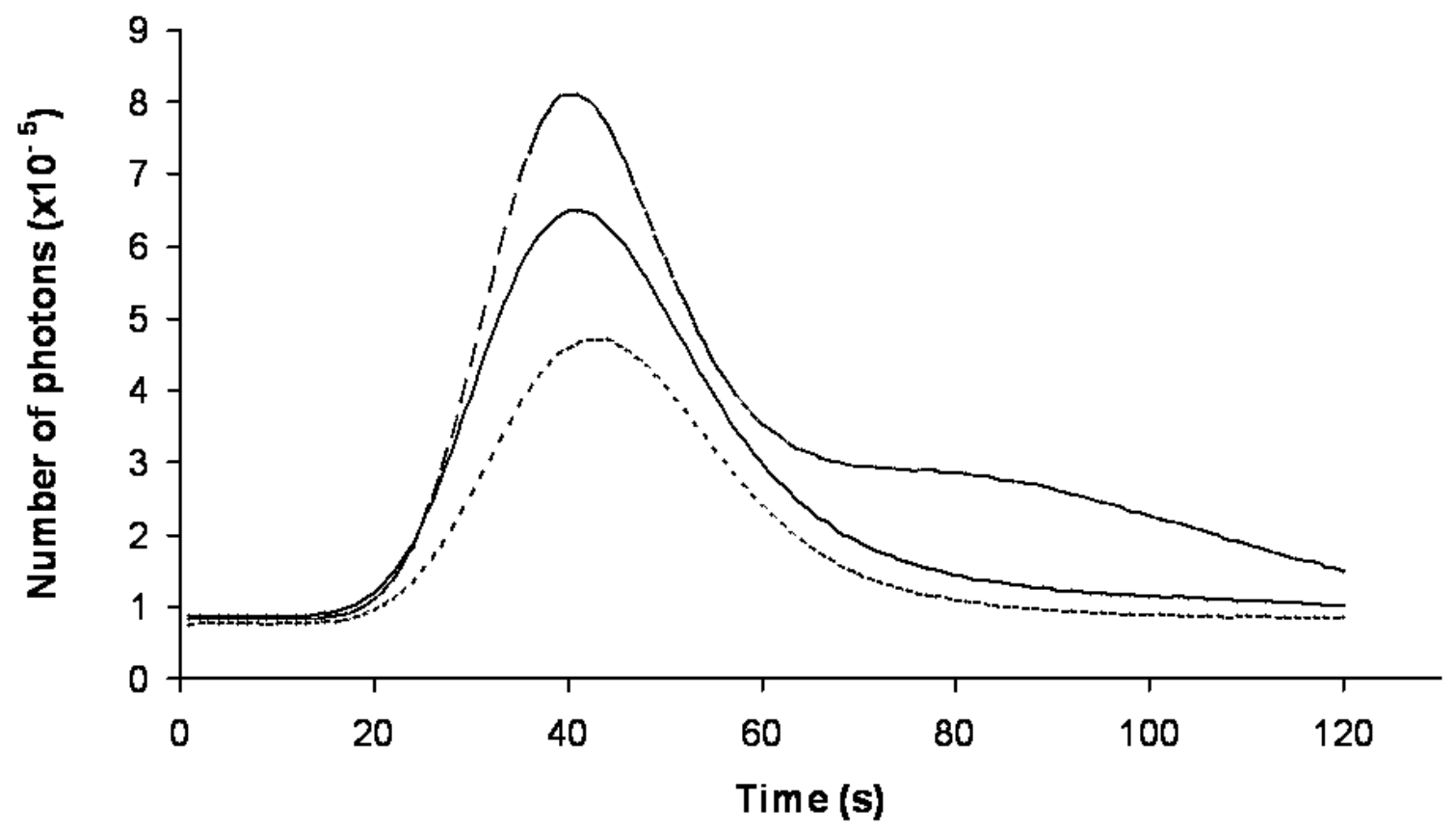

Figure 3: Chemiluminesence peaks obtained by injection of seawater $+6 \mathrm{nM}$ of hemin in different carriers: $\mathrm{MQ}$ water (dotted line), $\mathrm{NaCl}(0.5 \mathrm{M})$ (dark gray line), artificial seawater (light gray line). 

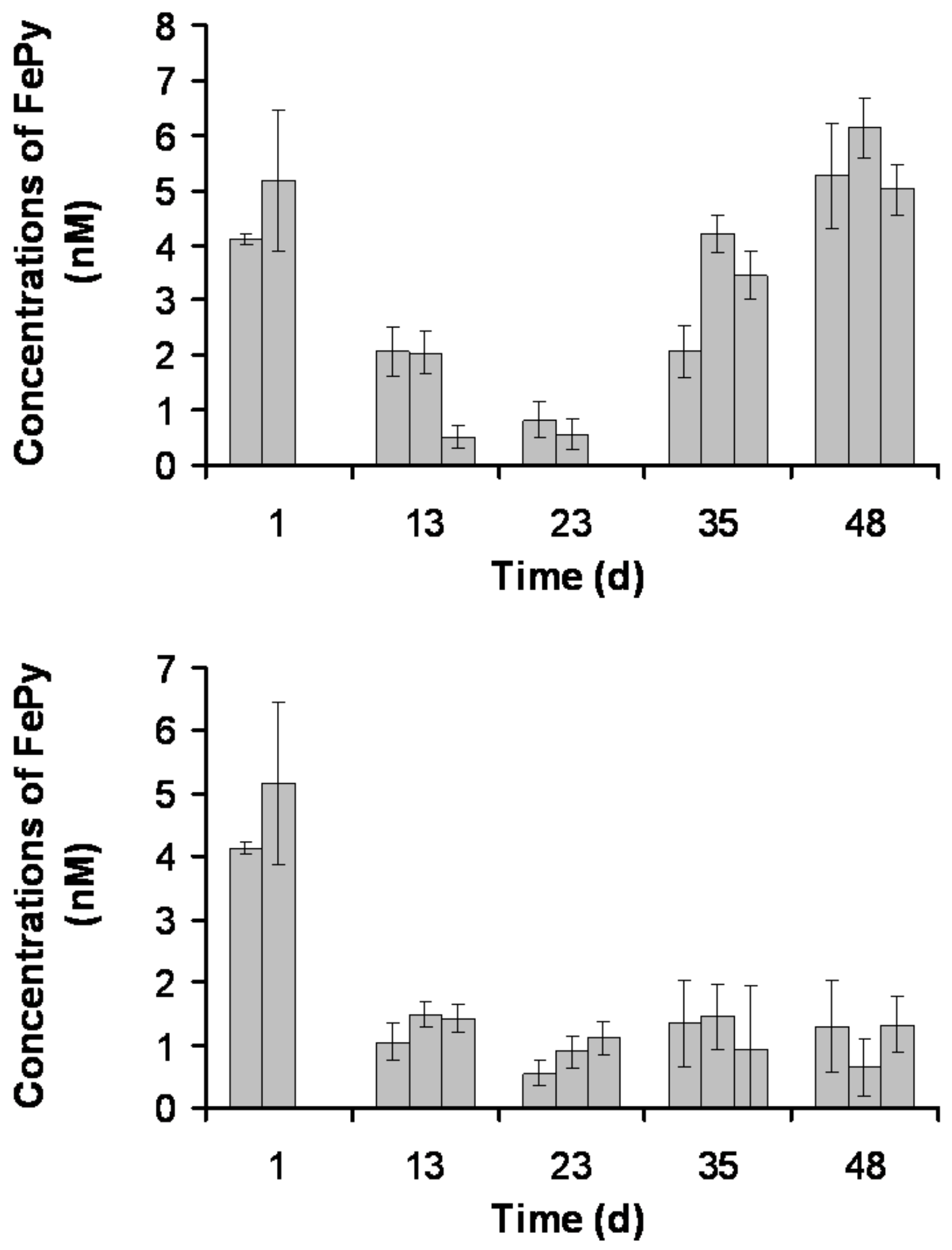

Figure 4: Stability of the sample (filtered river water) during storage: (a) at ambient temperature (b) frozen $\left(-20^{\circ} \mathrm{C}\right)$. 

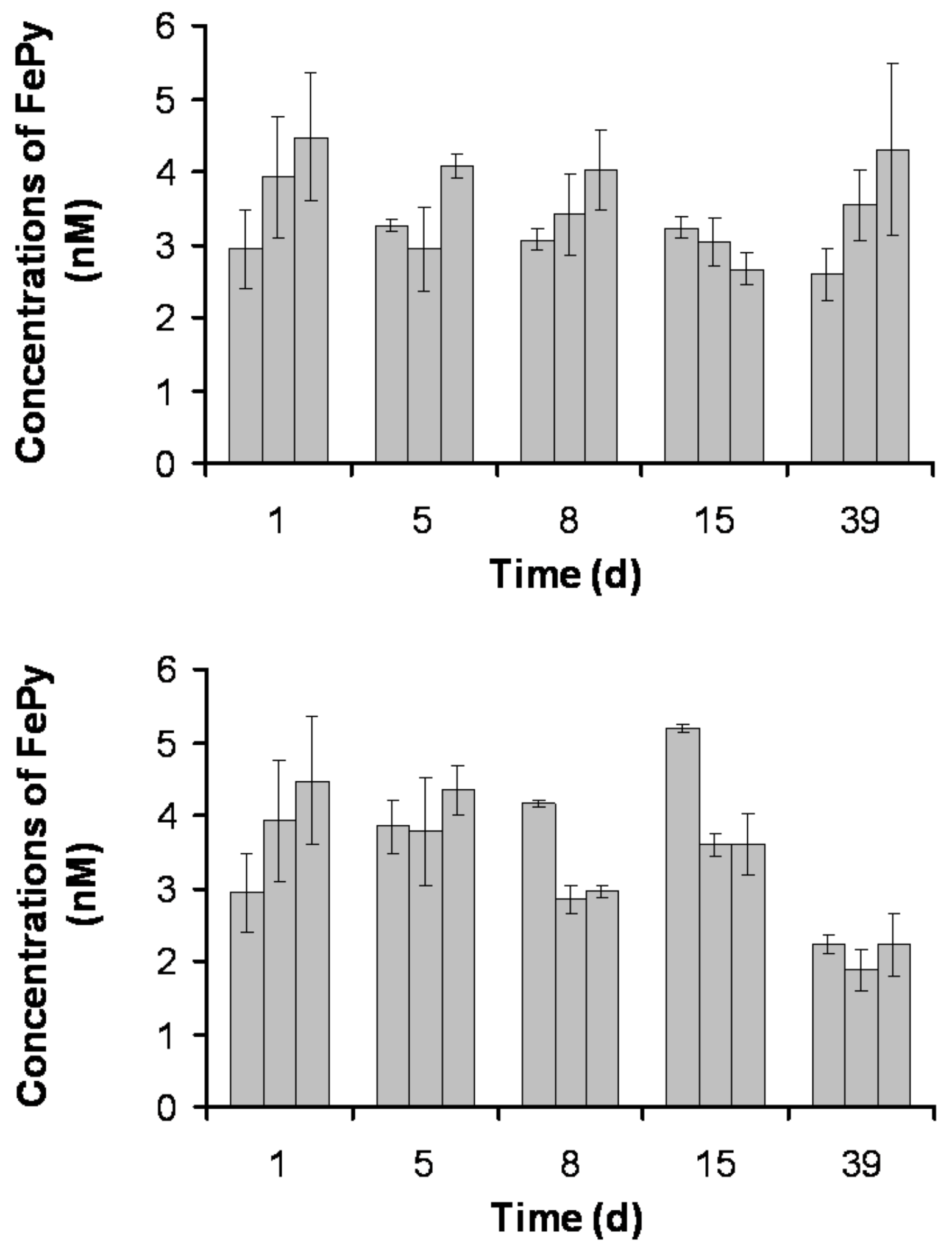

Figure 5: Stability of sample (river water). Non filtered and poisoned with $\mathrm{HgCl}_{2}$ : (a) at ambient temperature (b) frozen $\left(-20^{\circ} \mathrm{C}\right)$. 